Andrzej Prinke

(Polska Akademia Nauk - Archiwum w Warszawie - Oddział w Poznaniu)

dr, andrzej.prinke@gmail.com

\title{
Wielkopolanin w Warszawie. Stołeczne kontakty prof. Józefa Kostrzewskiego (1885-1969) - czołowego polskiego prehistoryka i muzeologa ${ }^{1}$
}

Prof. Józef Kostrzewski (1885-1969) - czołowy polski prehistoryk i muzeolog XX w., a jednocześnie wszechstronny działacz społeczny, przez całe swoje długie i pracowite życie związany był z Poznaniem i Wielkopolską (ryc. 1)². Podobnie jak wielu innych przedstawicieli pokolenia epoki zaborów, przejawiał on pewne uprzedzenia wobec rodaków z pozostałych dwóch zaborów, które jednak w wielu indywidualnych przypadkach, po zawarciu bliższej znajomości, skutecznie przezwyciężał. W rodakach pochodzących „,z tamtych stron" ${ }^{3}$ - jak mawiano wówczas w Poznaniu, zyskiwał nieraz bliskich i serdecznych przyjaciół ${ }^{4}$. Dużo trudniej, niż do ludzi, przychodziło mu przełamywać niechęć do miejsc, do których z pewnych powodów był uprzedzony. Jednym z nich była Warszawa, co również wynikało z powszechnych między-

${ }^{1}$ Pierwotną wersję poniższego tekstu autor przedstawił $\mathrm{w}$ formie referatu na konferencji pt. „Warszawa ma wiele twarzy” z cyklu „Warszawska Jesień Archiwalna”, zorganizowanej w Warszawie 21-22 listopada 2014 r. przez Instytut Historii Uniwersytetu Warszawskiego, Instytut Pamięci Narodowej - Centrum Edukacyjne im. Janusza Kurtyki, Naczelną Dyrekcję Archiwów Państwowych i Polską Akademię Nauk - Archiwum w Warszawie.

2 Kontekst opisywanych tu wydarzeń przedstawiono szerzej w: J. Kaczmarek, A. Prinke, Życie długie, pracowite i spetnione. Profesor Józef Kostrzewski (1885-1969), prehistoryk, patriota, Europejczyk, Poznań 2015 [w druku].

${ }^{3}$ Jeszcze dobitniejszym (i zawierającym ładunek wyraźnie negatywnych emocji) było potoczne poznańskie określenie Kungresówa z Galilejom.

${ }^{4}$ Np.: pochodzący spod Kijowa Tadeusz Zgierski-Strumiłło (1884-1958) - pedagog i filozof, czołowy działacz Stowarzyszenia Patriotyczno-Religijnego Eleusis, Jan Czekanowski (1882-1968) - prof. antropologii (Lwów), czy Stanisław Pigoń (1885-1968) - Galicjanin, prof. polonistyki na UJ. 


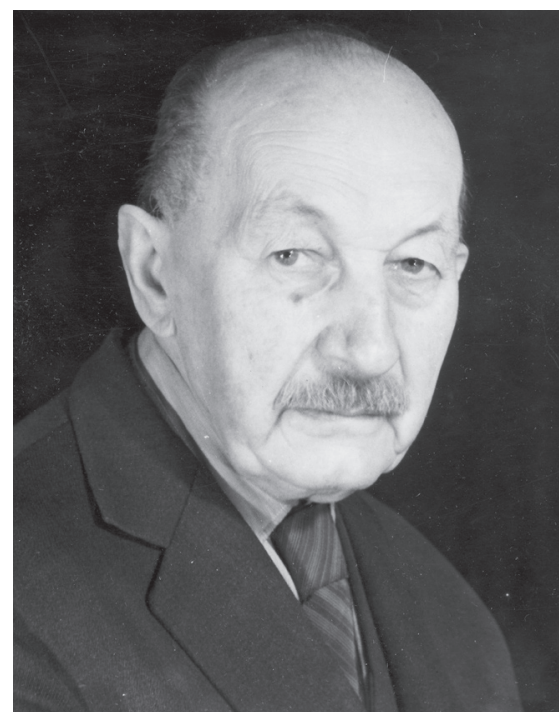

Ryc. 1. Dr Józef Kostrzewski, prehistoryk. Profesor Uniwersytetu Poznańskiego / Uniwersytetu im. Adama Mickiewicza w Poznaniu. Doktor honoris causa Uniwersytetu Jagiellońskiego w Krakowie, Uniwersytetu Karola w Pradze i Uniwersytetu im. Adama Mickiewicza w Poznaniu, członek czynny Polskiej Akademii Umiejętności w Krakowie, członek rzeczywisty Polskiej Akademii Nauk w Warszawie

zaborowych uprzedzeń i stereotypów (ryc. 2). W przypadku Kostrzewskiego dodatkowym źródłem uprzedzeń była z pewnością trauma po jego pierwszej, nader pechowej wizycie w styczniu 1909 r. Kostrzewski studiował wówczas (od 1907 r.) medycynę we Wrocławiu (Schlesische Friedrich Wilhelm-Universität zu Breslau / Śląski Uniwersytet Fryderyka Wilhelma we Wrocławiu), a jednocześnie już od lat gimnazjalnych zaangażowany był w - powszechną wśród ówczesnej młodzieży polskiej nielegalną działalność patriotyczną. I właśnie z tym kierunkiem aktywności młodego Józefa wiązał się jego pierwszy wyjazd do Warszawy. 12 stycznia 1909 r. miał się tam odbyć "tajny zjazd młodzieży filomackiej ze wszystkich dzielnic Polski" 5 , zorganizowany przez jedną z wielu organizacji konspiracyjnych, nawiązujących do tradycji okresu romantyzmu. Kostrzewski zamieszkał u jednego z organizatorów - studenta Michalskiego ${ }^{6}$, który - jak na konspiratora - wykazał się ogromną niefrasobliwością, gdyż szczegóły spotkania uzgadniał z pozostałymi uczestnikami telefonicznie. Zjazd odbywał się „, mieszkaniu przy ul. Wilczej 50, należącym do wdowy po generale rosyjskim - Polaku"7. Jak można było przewidzieć, tajna carska policja polityczna (Ochrana) zjawiła się tam już drugiego dnia, zaaresztowała ok. trzydziestu uczestników i osadziła ich $\mathrm{w}$ areszcie (ryc. 3$)^{8}$, a następnie $\mathrm{w}$ więzieniu ${ }^{9}$.

${ }^{5}$ J. Kostrzewski, Z mego życia. Pamiętnik, Wrocław 1970, s. 54.

${ }^{6}$ Imienia nie udało się ustalić.

7 J. Kostrzewski, dz. cyt., s. 54. Obie wymienione osoby zdołano zidentyfikować w oparciu o informacje ówczesnej prasy warszawskiej, Byli to: gen. Walerian Żyrkiewicz-Furs (1848-1906) i Janina z Bobińskich Żyrkiewiczowa, pisarka, córka Sylwana - uczestnika spisku Szymona Konarskiego. Zbiorowe aresztowanie, „Kurjer Polski” 1909, nr 13, s. 2.

${ }^{8}$ Areszt Centralny (tzw. „Centralniak”), mieszczący się przy ul. Daniłowiczowskiej 7 (na tyłach Ratusza).

${ }^{9}$ Więzienie przy ul. Spokojnej; J. Kostrzewski, dz. cyt., s. 54-58. Z nowego więzienia, „Nowa Gazeta" 1908, nr 287, s. 2. Edw[ard] Grab[owski], Ankieta więzienna. Więzienie na ul. Spokojnej, „Prawda” 1909, nr 49, s. 7-8; 1909, nr 50, s. 6-8; 1909, nr 51, s. 4-7; 1909, nr 52, s. 3-5. 


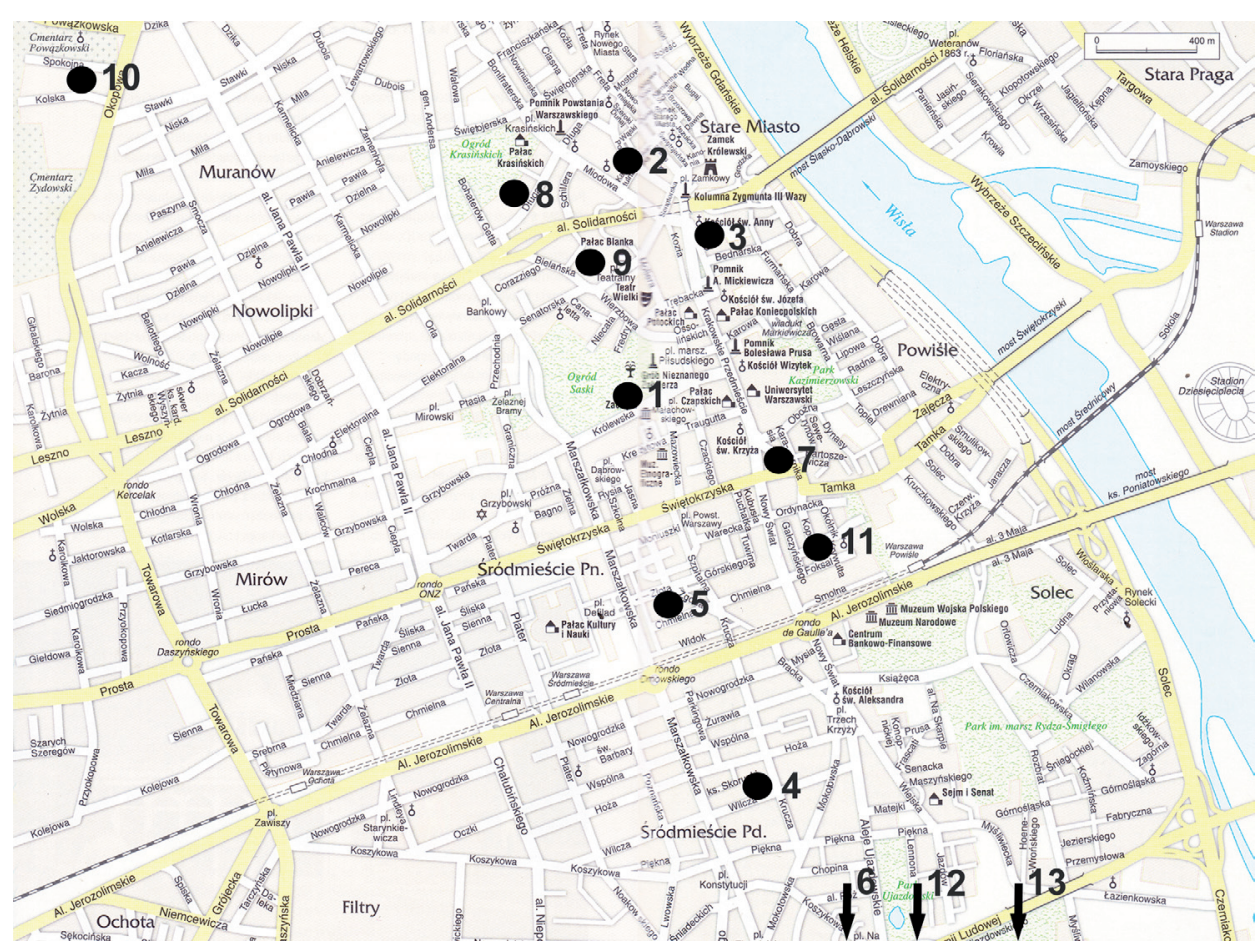

Ryc. 2. Warszawa Józefa Kostrzewskiego:

(1) - Towarzystwo Zachęty Sztuk Pięknych, pl. Małachowskiego 3. (2) - nowa siedziba Muzeum Sztuk Pięknych, ul. Podwale 15. (3) - Muzeum Przemysłu i Rolnictwa: ul. Krakowskie Przedmieście 15. (4) - miejsce tajnego spotkania młodzieży filareckiej z trzech zaborów, ul. Wilcza 50 (stancja studencka u Janiny z Bobińskich Żyrkiewiczowej, wdowy po generale carskim - Polaku, Walerianie Żyrkiewiczu-Fursie (1848-1906). (5) - mieszkanie Erazma Majewskiego, ul. Złota 61. (6) - siedziba Państwowego Muzeum Archeologicznego po 1950 r., ul. Chocimska 18. (7) - Pałac Staszica, ul. Nowy Świat 72 (a - Warszawskie Towarzystwo Naukowe, b - Katedra Archeologii Prehistorycznej UW, c - Grono Konserwatorów Zabytków Przedhistorycznych, d - Muzeum Erazma Majewskiego, e - mieszkanie Włodzimierza Antoniewicza). (8) - Instytut Historii Kultury Materialnej PAN, ul. Długa 26. (9) - areszt śledczy, ul. Daniłowiczowska 7, u wylotu ul. Hipotecznej (budynek nie istnieje). (10) - więzienie śledcze, ul. Spokojna 15 (budynek nie istnieje). (11) - mieszkanie Romana Jakimowicza, ul. Szczygla 5 m. 7. (12) - mieszkanie Konrada Jażdżewskiego, ul. Nabielaka 9. (13) - siedziba Państwowego Muzeum Archeologicznego do 1945 r., ul. Agrykola 9.

Opracował Andrzej Prinke; grafika komputerowa Wiesława Czerpińska.

W swym pamiętniku Kostrzewski szczegółowo opisuje prymitywne i uciążliwe warunki, jakie tam napotkał; jeszcze bardziej szokowało go wszechobecne skorumpowanie carskich funkcjonariuszy i urzędników. Aresztanci mogli zamawiać potrzebne towary u strażników więziennych, płacąc dziesięcioprocentowy narzut, a naczelnik więzienia - Aleksy Michajłowicz Nazarow żądał cotygodniowych łapówek jedynie za to, że nie odsyłał więźniów do jesz- 


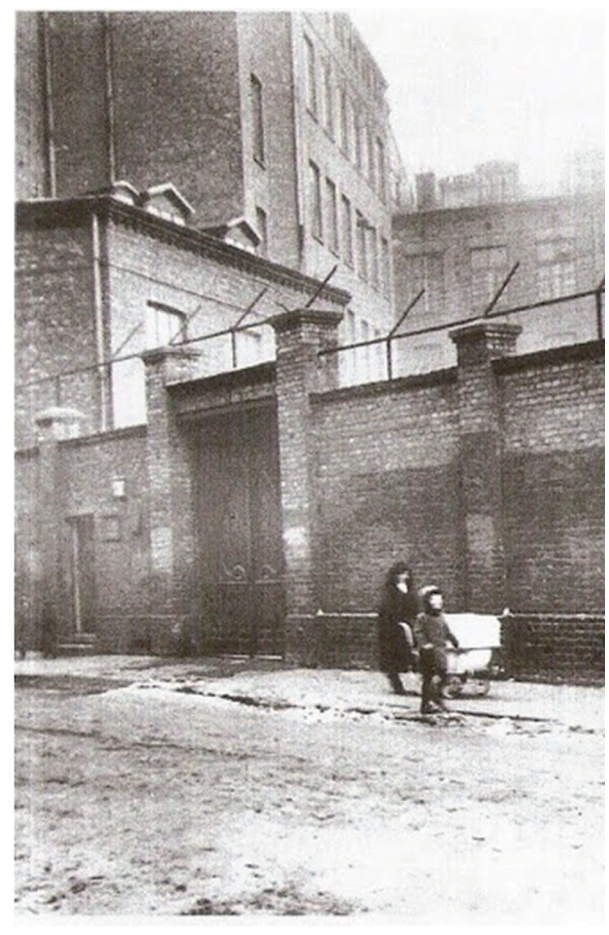

Ryc. 3. Areszt Centralny („Centalniak”) przy ul. Daniłowiczowskiej 7 (na tyłach ratusza). cze gorszego więzienia. Kostrzewski przyznaje jednocześnie, że był to człowiek $w$ gruncie rzeczy sympatyczny, który starał się umilać więźniom czas plotkami i dowcipami, a nawet przynosił im fotografie aktorek $^{10}$. Mieszkając we wspólnej celi, śpiąc na podłodze na drewnianych narach i korzystając $\mathrm{z}$ dziesięcioosobowych toalet bez przepierzen, aresztanci mieli szansę lepiej się poznać. Młody, bo zaledwie 24-letni Kostrzewski zetknął się tam z kilkoma wybitnymi działaczami patriotycznymi. Jego ponad pięciotygodniowy pobyt $\mathrm{w}$ celi nie był więc czasem straconym, lecz stał się swoistą ,"szkołą konspiracji”. Towarzysze niedoli to m.in.: były mnich Izydor Wysłouch $^{11}$ - przywódca ludowy i robotniczy, a w okresie międzywojennym działacz masonerii; Tadeusz Błażejewicz ${ }^{12}$ - działacz młodzieżowy, późniejszy poseł na sejm RP I ka-

10 Tamże, lecz wymieniony błędnie jako: Nazarew. Por.: Adresy Warszawy rok 1909, Antoni Żwan (red.), Warszawa 1909.

11 A nie zakonnik, jak u J. Kostrzewskiego, dz. cyt., s. 56. Izydor Kajetan Wysłouch (ur. 1869 w Pirkowiczach k. Drohiczyna, zm. 1937 w Warszawie), syn ziemianina; ukończył studia historyczne w Warszawie. Członek bezhabitowego Zgromadzenia Braci Sług Maryi, a następnie kolejno: założyciel Zgromadzenia Synów Boleści Maryi (doloryści), przełożony Zgromadzenia Sług Świętej Rodziny i kapucyn. Spadek po rodzicach przekazał ss. kapucynkom, złożył śluby wieczyste i przyjął święcenia kapłańskie. Po kryzysie wiary, od 1905 r. pod pseudonimem Antoni Szech zaproponował połączenie chrześcijaństwa z socjalizmem i patriotyzmem. W 1906 r. wystąpił ze stanu duchownego. Od 1919 r. jako pracownik Ministerstwa Pracy i Opieki Społecznej był współtwórcą polskiego ustawodawstwa socjalnego. Członek loży masońskiej Kopernik, ps. Antoni Sławicz (od 1932 r.). Remigiusz Okraska, Za szczęście wasze i nasze, czyli polska teologia wyzwolenia, http:/ / nowyobywatel.pl/2011/07/27/za-szczescie-wasze-inasze-czyli-polska-teologia-wyzwolenia/ (dostęp 18 marca 2015).

12 Nie był posłem do Dumy Państwowej, jak u J. Kostrzewskiego, dz. cyt., s. 56. Tadeusz Błażejewicz, (ur. 1880 w Lublinie, zm. 1966 w Łodzi); absolwent Wydziału Prawa Uniwersytetu w Dorpacie (1906), członek Stowarzyszenia Robotników Chrześcijańskich w Warszawie, gdzie był więziony przez trzy miesiące (1908-1909); redaktor miesięcznika „Prąd” (1908-1914). I wojnę światową spędził w Mińsku, ucząc i pracując społecznie. Radca w Ministerstwie Wyznań Religijnych i Oświecenia Publicznego (od 1920 r.). Poseł na sejm I i II kadencji z ramienia Naro- 
dencji; Aleksander Zwierzyński ${ }^{13}$ - dziennikarz i poseł, czy Bronisław Zału$\mathrm{ski}^{14}$ - działacz młodzieżowy, marianin. Ten ostatni był znajomym Cecylii Plater-Zyberkówny ${ }^{15}$, dzięki czemu czterej aresztowani mogli liczyć na lepsze obiady z miasta.

Józef szybko zorientował się, że nikt nie zamierza go przesłuchiwać, ani tym bardziej zwolnić. Kiedy dowiedział się, że jeden $\mathrm{z}$ więziennych towarzyszy przebywa tu już dwa lata bez przesłuchania, postanowił sam walczyć o własną wolność. Po namyśle napisał list do kuzyna Romana Krysińskiego z Ostrowa Wlkp., informując go o swoim położeniu. Pomysł okazał się skuteczny: z Ostrowa Wlkp. było blisko do granicy Imperium Rosyjskiego, a miejscowi kupcy, do których należała rodzina matki Kostrzewskiego, mieli stałe kontakty z kontrahentami z Rosyjskiej Polski ${ }^{16}$ i dobrze znali tamtejsze realia. Krysiński osobiście zjawił się w Warszawie i dotarł do mecenasa Stanisława van der Noot Kijeńskiego ${ }^{17}$, który miał praktykę w rozwiązywaniu tego typu

dowo-Chrześcijańskiego Stronnictwa Pracy. Chrześcijański działacz społeczny. libr.sejm.gov. pl/publish/ARS10/01/06/00/00/ARS10.000000106.html (dostęp 1 grudnia 2017).

${ }^{13}$ A nie Zwierzycki, marszałek senatu, jak u J. Kostrzewskiego, dz. cyt., s. 56. Aleksander Zwierzyński (ur. 1880, zm. 1958 w Tuszynie); studia prawnicze na UW i w École d'études politiques; członek Ligi Narodowej (od 1905 r.); dziennikarz wileński (od 1907 r.); poseł z ramienia Związku Ludowo-Narodowego (1922), wicemarszałek sejmu. Pobity przez oficerów za zamieszczenie krytycznego artykułu o Józefie Piłsudskim (1938). II wojna światowa - w konspiracji; wiceprezes Rady Jedności Narodowej (1944); aresztowany przez NKWD i UB, wywieziony do Moskwy, skazany w Procesie Szesnastu (17-21 czerwca 1945 r.). W listopadzie 1945 r. powrócił do kraju; http://pl.wikipedia.org/wiki/Aleksander_Zwierzyński (dostęp 1 grudnia 2017).

14 Bronisław Jan Załuski ze Zbijewka koło Włocławka, ziemianin (ur. 1888, zm. 1963); uczył się w Szkole Handlowej we Włocławku (matura 1907), studiował w Warszawie. Współpracownik hr. Cecylii Plater-Zyberkówny z ukrytego zgromadzenia ss. posłanniczek, propagatorki katolickiego wychowania młodzieży. Studiował rolnictwo na UJ (1908-1914); członek zakonu marianów (od 1916). Działacz społeczny, asystent przy Katedrze Nasienioznawstwa i Uprawy Roślin w Szkole Głównej Gospodarstwa Wiejskiego w Warszawie. Od 1919 r. nauczyciel, a następnie dyrektor (od 1921 r.) gimnazjum mariańskiego w Warszawie-Bielany. Po wojnie, po usunięciu marianów z Bielan, przeniesiony do klasztoru w Skórcu. K. Trojan MIC, Pan Dyrektor, www.marianie.pl/index.php?page=pages\&text $=27 \& s u b=8($ dostęp 1 grudnia 2017); J. Zawadka, Dyrektor Bronistaw Zatuski, Warszawa 2003.

${ }^{15}$ Hr. Cecylia Plater-Zyberk z Kurlandii (ur. 1853, zm. 1920), działaczka społeczna, pedagog i publicystka, założycielka szkół i towarzystw społecznych. W 1880 r. osiadła w Warszawie; posiadała tytuł mistrzowski w cechu krawieckim; wstąpiła do bezhabitowego zgromadzenia sióstr Posłanniczek Najświętszego Serca Jezusowego; zaangażowała się w działalność charytatywną. Autorka około 35 książek i licznych artykułów. PSB 1981, t. 26, s. 693-694 (autor hasła: Tadeusz Górski).

${ }^{16} \mathrm{Tj}$. z zaboru rosyjskiego (tzw. Kongresówki).

17 Stanisław van der Noot Kijeński, wzięty adwokat warszawski, znany m. in. z obrony socjaldemokraty B. Grucmana [imienia nie zdołano ustalić], aresztowanego razem z Marcinem Kasprzakiem (1905); w okresie międzywojennym - obrońca z urzędu Eligiusza Niewiadomskiego, zabójcy prezydenta Gabriela Narutowicza. PSB 1966-1967, t. 12, s. 449-450. 
spraw. Szybko ustalono, że więzień odzyska wolność za odpowiednie łapówki dla naczelnika więzienia Nazarowa, naczelnika żandarmerii oraz mniejszą dla dozorcy więziennego, który miał osobiście odwieźć Kostrzewskiego na dworzec, wykupić bilet i przypilnować, by delikwent wsiadł do pociągu i odjecha1 ${ }^{18}$. Koszt całej operacji, wraz z honorarium mecenasa, wyniósł tysiąc rubli, czyli ponad dwa tysiące marek. Było to niewiele mniej niż ówczesna pierwsza roczna pensja asystenta naukowego w Muzeum Cesarza Fryderyka w Poznaniu.

Już od chwili aresztowania i zaznajomienia się z realiami rosyjskiego wymiaru sprawiedliwości aż do ponownego przekroczenia granicy pruskiej Józef Kostrzewski na bieżąco poznawał różnice między państwem cara i państwem kajzera. Zdumiewało go powszechne łapówkarstwo i stosowanie prawa uznaniowego. Porównywał to z pruską machiną urzędniczą, gdzie urzędnik był zobowiązany sprawnie wypełniać przepisy prawa. W sumie, warszawska przygoda Józefa trwała niemal półtora miesiąca i zakończyła się zabawnym incydentem na granicy w drodze powrotnej do Poznania; incydentem, który dobitnie ilustruje ówczesne różnice pomiędzy oboma zaborami:

Przy przejeździe przez granicę rosyjsko-pruską... musiałem... opłacić należność celną za figurkę katorżnika i bucik damski artystycznie wykonany z chleba... przez więźniów, które uznano za „Nippsache” (drobiazg artystyczny) i oclono sumą 10 fenigów. Nie mając dziesięciogroszówki wręczyłem celnikowi dwadzieścia fenigów i wsiadłem co prędzej do wagonu, żeby mi pociąg nie odjechał. Tymczasem pruski urzędnik celny biegł wzdłuż całego pociągu szukając mnie, żeby mi wręczyć nadwyżkę... i z wielkim zadowoleniem zwrócił mi resztę ${ }^{19}$.

Skutki owej patriotyczno-kryminalnej przygody warszawskiej dla medycznej kariery Kostrzewskiego były katastrofalne. Po dwumiesięcznej przerwie w nauce obawiał się wracać do Wrocławia. Wiedział, że nie zdąży już zaliczyć ćwiczeń $\mathrm{w}$ prosektorium, a więc $\mathrm{w}$ najlepszym razie musiałby powtarzać rok, o ile władze uniwersyteckie nie dowiedziałyby się o jego spiskowaniu w Warszawie, za co groziło relegowanie z uczelni. Zdecydował się więc przenieść do Krakowa i podjąć tam nowe studia, gdyż coraz bardziej pociągała go etnologia, szczególnie polska kultura ludowa, a także prehistoria.

Kolejna wizyta Józefa Kostrzewskiego w Warszawie nastąpiła w lipcu 1916 r. i miała dwa cele: uzupełnienie części materiałowej pracy doktorskiej przed jej publikacją ${ }^{20}$ oraz udział $\mathrm{w}$ reorganizacji muzeum prehistoryczne-

18 J. Kostrzewski, dz. cyt., s. 57-58.

19 Tamże, s. 58.

20 Obrona pracy doktorskiej Kostrzewskiego odbyła się w Berlinie 20 lipca 1914 r. (promotor: prof. Gustaf Kossinna), lecz po (opisanym powyżej) incydencie więziennym z 1909 r. Kostrzewski uważał powrót do Warszawy za niewskazany, dopóki pozostaje ona pod władzą Rosjan. Sytuacja zmieniła się po wkroczeniu tam 5 sierpnia 1915 r. wojsk niemieckich. 
go Erazma Majewskiego (przeprowadzka i uporządkowanie zbiorów oraz przygotowanie przewodnika; ryc. 4$)^{21}$. Mimo że Warszawa znalazła się pod okupacją niemiecką, od przyjezdnych wymagano specjalnych przepustek, gdyż teren ten podlegał administracji wojskowej. Kostrzewski pokonał tę przeszkodę, prosząc o rekomendację swego dawnego szefa z czasów studiów berlińskich - prof. Carla Schuchhardta $^{22}$. W rezultacie, mimo iż żona Kostrzewskiego sprawowała opiekę nad dwójką małych dzieci, a spodziewała się trzeciego, Józef wyruszył w drogę do Warszawy i 13 lipca 1916 r. zapukał do drzwi domu Erazma Majewskiego przy ul. Złotej 61. Nie przyjeżdżał tam jednak jako osoba urzędowa, lecz jako specjalista, za zgodą swej macierzystej instytucji

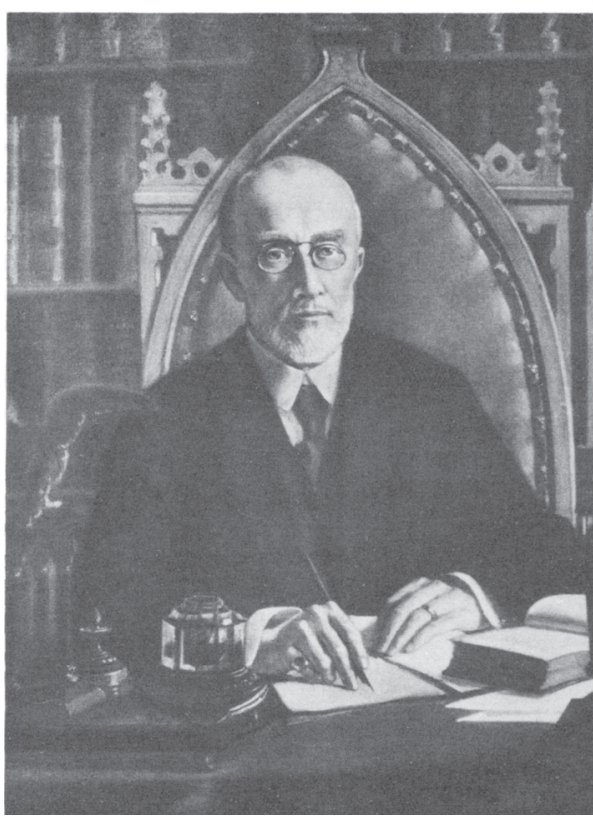

Ryc. 4. Erazm Majewski (1858-1922) archeolog, właściciel pierwszego muzeum zbiorów. i na zaproszenie właściciela.

Przez niemal dwa miesiące Józef Kostrzewski brał udział w przeprowadzce zbiorów z gmachu Towarzystwa Zachęty Sztuk Pięknych, położonego przy pl. Małachowskiego, do pomieszczenia po byłym cyrkule policji przy ul. Podwale 15. Budynek ten świeżo wynajęto na Muzeum Sztuk Pięknych²3,

${ }^{21}$ Erazm Majewski (ur. 1858 w Lublinie, zm. 1922 w Warszawie) - archeolog-samouk, bio$\log$, socjolog, filozof, ekonomista, etnograf i powieściopisarz. Zasłużony archeolog warszawski, jeden z pionierów ochrony zabytków archeologicznych na ziemiach polskich, twórca Dekalogu Archeologa. Członek Towarzystwa Naukowego Warszawskiego, Międzynarodowego Instytutu Socjologii; twórca czasopisma "Światowit" (od 1899 r.). Kolekcjoner zabytków - w 1908 r. w gmachu Towarzystwa Zachęty Sztuk Pięknych utworzył ze swoich zbiorów Muzeum Przedhistoryczne. Autor czterotomowej Nauki o cywilizacji. Pierwszy prezes Państwowego Grona Konserwatorów Zabytków Przedhistorycznych w II RP, od 1919 r. kierownik Katedry Archeologii Prehistorycznej UW. Erazm Majewski i warszawska szkoła prehistoryczna na poczatku XX wieku, red. S.K. Kozłowski i J. Lech, Warszawa 1996; PSB 1974, t. 19, s. 176-178 (autor hasła: Zbigniew Landau).

22 Carl Schuchhardt (ur. 6 sierpnia 1859 r., zm. 7 grudnia 1943 r.) - archeolog niemiecki, członek Pruskiej Akademii Nauk, dyrektor Działu Prehistorycznego Muzeum Etnologicznego w Berlinie, gdzie Kostrzewski pracował przez trzy miesiące w 1913 r.; założyciel rocznika „Praehistorische Zeitschrift".

${ }^{23}$ W 1915 r. muzeum to zostało przejęte przez Zarząd Miasta Warszawy. 
a Erazm Majewski miał tam otrzymać pomieszczenie na parterze. Przy okazji Kostrzewski sporządzał własny katalog zbiorów, niezbędny mu do uzupełnienia doktoratu i do dalszej pracy naukowej. Podobną dokumentację wykonał również w Muzeum Rolnictwa i Przemysłu. W pakowaniu zabytków i przewożeniu ich na otwartych platformach do nowej siedziby brało udział kilka osób, w tym Leon Kozłowski ${ }^{24}$, który wówczas pracował u Majewskiego i nie obronił jeszcze doktoratu ${ }^{25}$. O ile stosunki z gospodarzem układały się Kostrzewskiemu znakomicie, a Majewski w swych dziennikach z uznaniem wyrażał się o swoim gościu, to kontakty z Leonem Kozłowskim były pełne napięć. Pewną rolę odgrywały tu różnice polityczne - Kozłowski był socjalistą, współpracownikiem Józefa Piłsudskiego, legionistą i austrofilem, zaś Kostrzewski i Majewski byli zwolennikami Ententy. Kostrzewskiego najbardziej irytował w Kozłowskim fakt, że ten niewątpliwy polski patriota był wielkim ignorantem, jeśli chodzi o stosunki narodowościowe w zachodnich dzielnicach Polski (czyli w Wielkopolsce, na Pomorzu i Śląsku), marzyła mu się natomiast ekspansja na Wschód. Kozłowski twierdził np., że gdyby doszło do odzyskania przez Polskę Pomorza, to wówczas najbardziej polskim elementem byłby tam żandarm i nauczyciel ${ }^{26}$.

Gdy jednak część zbiorów znalazła sięjuż na nowym miejscu, a Kostrzewski zebrał większość materiałów potrzebnych do przewodnika, nowy dyrektor Muzeum Sztuk Pięknych - Bronisław Gembarzewski ${ }^{27}$ - zamknął pomiesz-

${ }^{24}$ Leon Tadeusz Kozłowski (ur. 1892 w Rembieszycach, zm. 1944 w Berlinie) - archeolog i polityk, poseł, senator, minister w różnych rządach, premier II RP (1934-1935, kiedy rozpoczęto budowę COP, ale i utworzono obóz w Berezie Kartuskiej). Syn ziemianina, podopieczny Erazma Majewskiego, uczeń Włodzimierza Demetrykiewicza w Krakowie i Roberta Rudolfa Schmidta w Tybindze. Przed 1914 r. należał m.in. do Związku Młodzieży Postępowej i Związku Strzeleckiego. Współpracownik Józefa Piłsudskiego. Podczas I wojny światowej służył w 1. Pułku Ułanów Legionów Polskich. W 1915 r. pracował przejściowo w Muzeum Erazma Majewskiego. Od 1917 r. w Polskiej Organizacji Wojskowej. Doktorat: Tybinga (Epoka kamienia na wydmach wschodniej części Wyżyny Małopolskiej, 1918). Habilitacja: Kraków (Groby megalityczne na wschód od Odry, 1920). Jako archeolog był przedstawicielem tzw. szkoły neoautochtonicznej. Ochotnik w wojnie 1920 r. W latach 1921-1931 i 1935-1939 - prof. archeologii na Uniwersytecie Jana Kazimierza we Lwowie. 26 września 1939 r. aresztowany przez NKWD we Lwowie; w Moskwie skazany na karę śmierci. Uwolniony w wyniku układu Sikorski-Majski, trafił do armii gen. Władysława Andersa. Opuściwszy oddziały polskie jesienią 1941 r., przedostał się na niemiecką stronę frontu. Internowany w Berlinie; za pracę $\mathrm{w}$ tamtejszym muzeum przyznano mu pensję. Zmarł na atak serca bądź w wyniku odniesionych ran 11 maja 1944 r. podczas nalotu alianckiego lub wkrótce po nim. PSB 1970, t. 15, s. $19-21$ (autorzy hasła: Konrad Jażdżewski i Tadeusz Jędruszczak); S.K. Kozłowski, Włodzimierz Antoniewicz, profesor $z$ Warszawy, Warszawa 2009.

${ }^{25}$ U J. Kostrzewskiego, dz. cyt., s. 90: doktor Leon Kozłowski.

26 Tamże, s. 90-91.

27 Bronisław Gembarzewski (ur. 1872 w Petersburgu, zm. 1941 w Warszawie) - płk saperów Wojska Polskiego (1921-1927), historyk wojskowości, muzeolog, dyrektor Muzeum Narodowego i Muzeum Wojska w Warszawie (od 1920 r.). Z ramienia Komitetu Obywatelskiego miasta 
czenia muzealne, zakazał ekipie Majewskiego wstępu do nich i zażądał ich opróżnienia ${ }^{28}$, do czego ostatecznie nie doszło. Dla Kostrzewskiego ta kolejna warszawska przygoda już się jednak kończyła, gdyż musiał wracać do swej stałej pracy w muzeum poznańskim. Pozostało zdobycie zezwolenia na wywóz dużej paczki dokumentacji, gdyż inaczej przy przekraczaniu granicy mogła ona zostać zarekwirowana, a przynajmniej zatrzymana na jakiś czas i zdekompletowana $\mathrm{w}$ czasie poszukiwania ewentualnych materiałów szpiegowskich. Taki glejt można było próbować uzyskać w niemieckiej komendanturze. Niespodziewanie Kostrzewski natknął się tam na swego niemieckiego kolegę szkolnego nazwiskiem Fobra, który ułatwił mu załatwienie wszelkich formalności. Aby przekroczyć granicę, tuż przed samym wyjazdem z Dworca Kaliskiego ${ }^{29}$ należało jeszcze uzyskać zaświadczenia o braku wszawicy i choroby zakaźnej. Otrzymywało się je bez badania, a jedynie po uiszczeniu odpowiedniej opłaty, z czego Józef Kostrzewski wywnioskował, że miało ono znaczenie wyłącznie fiskalne, a nie sanitarne ${ }^{30}$. Wyjazd z Warszawy nastąpił 5 września. Ostatecznie przewodnik po zbiorach Muzeum Majewskiego ukazał się bez daty i nazwiska autora w 1917 r. Niestety, nie był on kompletny, gdyż nie dość, iż Kostrzewski nie ukończył opisu całości zbiorów, to jeszcze część tekstu zagubiono $\mathrm{w}$ drukarni i wydrukowano zaledwie pierwszych osiemdziesiąt stron.

Następne ważne wydarzenie w relacjach Józefa Kostrzewskiego z Warszawą, już jako stolicą Polski Odrodzonej, dotyczy roku 1920, kiedy na świeżo otwartym Uniwersytecie Poznańskim (którego był jednym z głównych współzałożycieli) przeprowadzono pierwszy w niepodległej Polsce przewód habilitacyjny z prehistorii. Kandydatem był dr Włodzimierz Antoniewicz

Warszawy opiekował się gmachami państwowymi w latach 1915-1916. Członek Towarzystwa Opieki nad Zabytkami Przeszłości w Warszawie, Towarzystwa Naukowego Warszawskiego. Biogramy uczonych polskich, cz. I: Nauki społeczne, z. 1: A-J, Wrocław 1983; PSB 1948-1949, t. 7, s. 372-373 (autor hasła: Władysław Tomkiewicz).

${ }^{28}$ J. Kostrzewski, dz. cyt., s. 91, nazywa Gembarzewskiego dyrektorem Muzeum Narodowego, ale Zarząd Miasta Warszawy zmienił nazwę Muzeum Sztuk Pięknych na Muzeum Narodowe Miasta Stołecznego Warszawy dopiero 21 września 1916 r. (Materiały źródtowe do dziejów Muzeum Narodowego w Warszawie..., archiwum.amu.edu.pl/publikacje/13.pdf; dostęp 1 grudnia 2017), kiedy Kostrzewskiego już w Warszawie nie było. Być może incydent ten był jednym z powodów, iż, mimo namów Kostrzewskiego, Majewski nie zdecydował się przekazać swych zbiorów na własność państwu jako np. Muzeum Prehistoryczne im. Erazma Majewskiego, lecz ofiarował je Warszawskiemu Towarzystwu Naukowemu.

${ }^{29}$ Istniał on zaledwie kilka lat i przystosowany był do obsługi pociągów szerokotorowych.

30 Twierdząc to, Profesor nie miał racji, gdyż władze niemieckie bardzo obawiały się w tym czasie epidemii tyfusu, roznoszonego przez wszy i usilnie próbowały temu przeciwdziałać. J. Kostrzewski, dz. cyt., s. 91. Brak kontroli na granicy wynikał więc raczej z niesolidności urzędnika odpowiedzialnego za przestrzeganie tych procedur. 
z Warszawy ${ }^{31}$, który miał potem obowiązek przez jakiś czas prowadzić wykłady na uczelni.

W listopadzie 1921 r. Józef Kostrzewski, choć prowincjusz, objął stanowisko prezesa $\mathrm{w}$ nowo powstałej centralnej instytucji, jaką było Państwowe Grono Konserwatorów Zabytków Archeologicznych z siedzibą w Warszawie. Dotychczasowy prezes - prof. Erazm Majewski - zrzekł się tej funkcji ze względów zdrowotnych. Główne cele działalności Grona, to likwidacja podziałów między byłymi zaborami oraz wypracowanie jednolitej polityki archeologiczno-konserwatorskiej. Po dwóch latach Kostrzewski zrezygnował z powyższej funkcji, uznając, że nie da się jej skutecznie wypełniać, mieszkając w Poznaniu, zwłaszcza w obliczu ostrego konfliktu w łonie prezydium Grona.

Wkrótce po śmierci Erazma Majewskiego, który pod koniec życia zdążył jeszcze zostać profesorem Uniwersytetu Warszawskiego, Józef Kostrzewski otrzymał propozycję objęcia po nim tamtejszej Katedry Prehistorii (26 lutego 1923 r.), jednakże odrzucił ją, uzasadniając to swymi bliskimi związkami z Poznaniem i Wielkopolską ${ }^{32}$.

Warszawa pojawia się $\mathrm{w}$ biografii prof. Kostrzewskiego ponownie tuż po wybuchu II wojny światowej. Jego najstarszy syn Zbigniew (1913-1955) zgłosił się wtedy na ochotnika do obrony stolicy, a po jej kapitulacji, wzorem wielu innych żołnierzy polskich, zdołał przedostać się przez Węgry do Francji ${ }^{33}$. Ewakuując się wraz z rodziną z Poznania, Józef Kostrzewski zakładał, że miejscem względnie bezpiecznym będzie oddalone o dwieście km od ówczesnej granicy polsko-niemieckiej Koło. Wkrótce jednak niemiecki nalot na to miasto spowodował zmianę decyzji. Profesor postanowił teraz dotrzeć wraz z rodziną do swego brata Wacława, który był wówczas rządcą majątku w Mogilanach na Wołyniu ${ }^{34}$. Trasa wędrówki wiodła przez Warszawę, dokąd

31 Włodzimierz Antoniewicz (ur. 1893, zm. 1973) - archeolog; prof. (od 1924 r.) i rektor UW (1936-1939), kierownik Katedry Archeologii Pierwotnej UW; dyrektor Państwowego Muzeum Archeologicznego w Warszawie (od 1924 r.). Członek PAN.

32 J. Kostrzewski, dz. cyt., s. 125-126.

33 Zbigniew Kostrzewski (ur. 1913, zm. 1955) - najstarszy syn Józefa Kostrzewskiego; absolwent Wydziału Prawa UP, adwokat. Podczas II wojny światowej brał udział w obronie Warszawy (Krzyż Walecznych), po czym zbiegł do Francji, gdzie walczył w szeregach II Dywizji Strzelców Pieszych pod dowództwem gen. Bronisława Prugar-Ketlinga; po klęsce Francji, wraz z całą dywizją został internowany w Szwajcarii; w 1944 r. przez wyzwoloną już Francję zbiegł do Wielkiej Brytanii, gdzie wstąpił do Polskich Sił Zbrojnych na Zachodzie; do Polski powrócił w roku 1946 wraz z żoną Jean z d. Anderson, pochodzącą z Meigle w Szkocji.

34 Wieś Mogilany (obecnie Mohylyany), położona czterdzieści km na południowy wschód od Równego (obecnie Ukraina); do roku 1939 - w gminie Sijańce (obecnie Siyantsi), powiat Zdołbunów (obecnie Zdolbuniv); właścicielem majątku był Konstanty Martynek; Księga adresowa Polski (wraz z W.M. Gdańskiem) dla handlu, przemystu, rzemiost i rolnictwa, Warszawa 1928. Towarzystwo Reklamy Międzynarodowej, sp. z o.o. Dzisiejsze Mohylyany należą do rejonu Ostroh (obwód Rivne) na Ukrainie. 
uchodźcy dotarli po wielu perypetiach, szczegółowo opisanych w pamiętniku Profesora ${ }^{35}$.

Opuszczenie Poznania 3 września $1939 \mathrm{r}$. to jeden $\mathrm{z}$ najbardziej dramatycznych momentów w życiu Józefa Kostrzewskiego. W jednej chwili zmuszony był porzucić cały, wznoszony przez niego praktycznie od zera przez poprzednie 25 lat, tj. od chwili podjęcia pracy prehistoryka w Muzeum im. Mielżyńskich w Poznaniu (1 kwietnia $1914 \mathrm{r}$.) gmach poznańskiej archeologii. Tym samym utracił to, co było najgłębszym sensem jego życia: zbiory muzealne, katedrę uniwersytecką z gronem uczniów i współpracowników, zaplecze laboratoryjne, Ekspedycję Biskupińską UP i wreszcie - własny warsztat naukowy w nowo wzniesionym (1932), rodzinnym domu w Strzeszynku, czyli wszystkie czę-

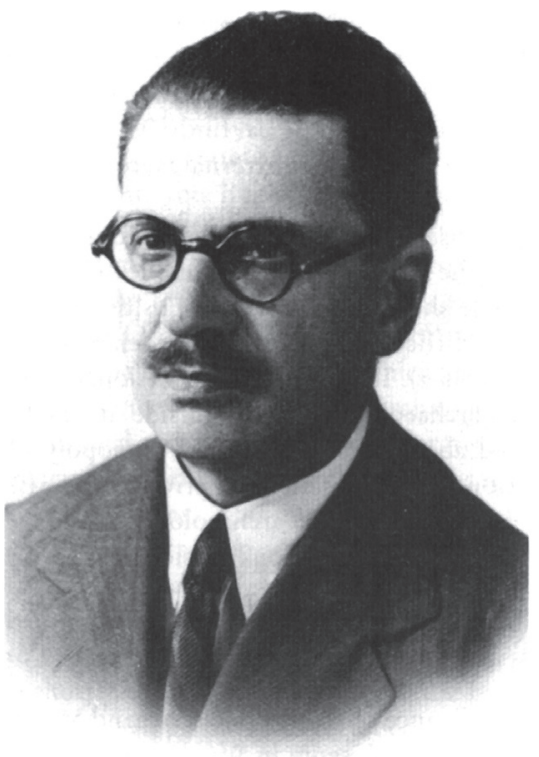

Ryc. 5. Roman Jakimowicz (1889-1951) archeolog, twórca i dyrektor Państwowego Muzeum Archeologicznego w Warszawie. ści składowe tego, co nazywamy dziś poznańską szkołą archeologiczną; to, czego był niekwestionowanym twórcą i szefem. Co więcej, Kostrzewski porzucał to swoje archeologiczne gospodarstwo bez żadnej gwarancji powrotu, za to z pełną świadomością, że już za chwilę dostanie się ono w ręce jego naukowych - a i ideowych - rywali i przeciwników, a obecnie - wręcz wrogów: niemieckiej administracji okupacyjnej i przedstawicieli zideologizowanej, narodowo-socjalistycznej archeologii niemieckiej. I tak się też stało.

W Warszawie rodzina Kostrzewskich zatrzymała się na krótko u doc. Romana Jakimowicza (ryc. 5) ${ }^{36}$, dyrektora Państwowego Muzeum Archeologicznego w Warszawie, a zarazem kolegi po fachu i bliskiego przyjaciela Profesora, po czym ruszyła w dalszą drogę na Kresy. Wkrótce jednak Profesor

35 Tamże, s. 220-221.

${ }^{36}$ Roman Jakimowicz (ur. 1889, zm. 1951), archeolog i muzeolog; studiował we Lwowie, Krakowie i w Pradze; redaktor „Wiadomości Archeologicznych” (1924-1939); twórca i dyrektor (1928-1939) Państwowego Muzeum Archeologicznego w Warszawie, od 1946 r. prof. Uniwersytetu Mikołaja Kopernika w Toruniu. Przyczynił się m.in. do powstania rezerwatu archeologicznego w Krzemionkach Opatowskich. PSB 1962-1964, t. 10, s. 331-332 (autor hasła: Witold Hensel). 
ponownie zmienił plany - być może wiedziony intuicją, bo na cztery dni przed sowiecką inwazją 17 września zawrócił, już z Kresów, do Poznania.

Ostatecznie Kostrzewski opuścił Poznań na dobre 15 grudnia 1939 r., po zaopatrzeniu się $\mathrm{w}$ fałszywy dowód tożsamości oraz przepustkę niezbędną do wyjazdu, otrzymał bowiem ostrzeżenie, iż Gestapo wydało nakaz jego aresztowania. Okupacyjna tułaczka trwała w sumie ponad pięć lat. Profesor udał się ponownie do Warszawy ${ }^{37}$, lecz tym razem zatrzymał się u rodziny swego wieloletniego przyjaciela z bractwa Eleusis - Karola KurtzmannaKarlińskiego ${ }^{38}$. Poza samym schronieniem otrzymał tam możliwość zameldowania, a nawet przydziały kartkowe. Listy do rodziny podpisywał odtąd jako Zosia i praktykę tę stosował aż do końca wojny. Wkrótce, po nieudanej próbie ucieczki na Węgry, dołączyli do niego synowie Bogdan i Przemysław; zapewne zamierzali oni podążyć w ślad za swym starszym bratem Zbigniewem. Obaj młodsi synowie udali się wkrótce do Gorlic, by szukać możliwości przetrwania w nowych, okupacyjnych warunkach ${ }^{39}$. Pod koniec roku żona Profesora Jadwiga, wraz z córką Marią Jagienką, opuściły Poznań, chcąc uniknąć grożącej im wywózki, szeroko praktykowanej przez władze okupacyjne, zwłaszcza wobec właścicieli atrakcyjnych lokali mieszkalnych. Po kilku dniach postoju w Warszawie obie panie dotarły do Gorlic, gdzie dołączyły do Bogdana i Przemka ${ }^{40}$.

W początkach marca 1940 r. Profesor podziękował pp. Kurtzmannom za wyjątkową, trzymiesięczną gościnę i przeniósł się do następnej kryjówki. Jak na jego ówczesne tragiczne położenie, było to miejsce ze wszech miar korzystne: tzw. Kolonia Elsowo, wzniesiona w okresie międzywojennym w Burzynie koło Tuchowa (pow. tarnowski) ze składek członkowskich stowarzyszenia patriotyczno-religijnego Filarecki Związek Elsów, którego Kostrzewski był aktywnym działaczem niemal od chwili jego założenia przez prof. Wincentego Lutosławskiego (1902). Elsowo miało służyć jako centrum spotkań i ośrodek wypoczynkowy (tzw. Dom Filarecki), a w przyszłości - również jako miejsce stałego zamieszkania części rodzin elsowskich.

Warszawskie kontakty Kostrzewskiego wieńczy akcent optymistyczny: w roku 1966 Prezydium Rady Narodowej Miasta Stołecznego Warszawy przyznało Profesorowi Odznakę Honorową za Zasługi dla Warszawy (poprzednio otrzymał on podobne wyróżnienia od władz Gniezna, Opola i Poznania oraz woj. poznańskiego i szczecińskiego).

37 J. Kostrzewski, dz. cyt., s. 227-228.

${ }^{38}$ Karol Ludwik Kurtzmann-Karliński (ur. 1882, zm. 1951; pseudonim elsowski „Wicher”); podczas I wojny światowej podporucznik żandarmerii.

39 J. Kostrzewski, dz. cyt., s. 228. Z Gorlic pochodził uczeń Profesora i absolwent poznańskiej prehistorii - Jacek Delekta, co prawdopodobnie miało wpływ na decyzję obu braci.

${ }^{40}$ Tamże. 
Andrzej Prinke

\title{
Wielkopolanin w Warszawie. Stołeczne kontakty prof. Józefa Kostrzewskiego (1885-1969) - czołowego polskiego prehistoryka i muzeologa
}

\section{Streszczenie}

W artykule przedstawiono - w oparciu o źródła archiwalne - nieznane szczegóły kontaktów prof. Józefa Kostrzewskiego, czołowego polskiego prehistoryka i muzeologa, ze środowiskiem warszawskim. Kontakty te wykraczały poza wąsko pojętą współpracę zawodową, obejmując również wielostronną działalność społeczną i patriotyczną.

Słowa kluczowe: historia archeologii, Kostrzewski Józef, Majewski Erazm, Kozłowski Leon, Warszawa

\section{Inhabitant of Great Poland in Warsaw. The Warsaw contacts of professor Józef Kostrzewski (1885-1969), a prominent Polish prehistorian and museologist}

\begin{abstract}
The article presents unknown details concerning the contacts of professor Józef Kostrzewski, a prominent Polish prehistorian and museologist, with the Warsaw circles, based on archival materials. These contacts went beyond purely professional collaboration, also involving social and patriotic activities.
\end{abstract}

Keywords: history of archeology, Kostrzewski Józef, Majewski Erazm, Kozłowski Leon, Warsaw 